\title{
Arsanilic acid, sodium salicylate and bromide salts as potential growth stimulants for pigs receiving diets with and without copper sulphate
}

\author{
By R. S. BARBER, R. BRAUDE AND K. G. MITCHELL \\ National Institute for Research in Dairying, Shinfield, Reading $R G 29 A$
}

(Received 25 Fune 1970-Accepted I 5 October 1970)

\begin{abstract}
I. Results are presented of three experiments involving $\mathrm{I} I 2$ individually fed pigs, covering the growing period between 20 and $90 \mathrm{~kg}$ live weight, in which the potential performance-stimulating properties of three different compounds were studied in relation to those of a dietary supplement of $250 \mathrm{mg} \mathrm{Cu} / \mathrm{kg}$ diet.

2. The three compounds studied and the levels of supplementation used ( $\mathrm{mg} / \mathrm{kg} \mathrm{diet})$ were: Expt I arsanilic acid (100), Expt 2 sodium salicylate (200), Expt 3 a mixture iof bromide salts (200); each was added to the diets either alone or with $250 \mathrm{mg} \mathrm{Cu} / \mathrm{kg}$ diet given as $\mathrm{CuSO}_{4} \cdot 5 \mathrm{H}_{2} \mathrm{O}$.

3. The diets were given wet, 'to appetite' twice daily up to a daily maximum of $3 \mathrm{~kg}$ feed/pig. Measurements of length and of back-fat thickness at a number of points were made on all carcasses at slaughter.

4. Arsanilic acid and sodium salicylate alone gave growth responses similar to those obtained with $\mathrm{Cu}$ alone, whereas the bromide salt had no effect on performance. None of the three compounds when added to diets in conjunction with $250 \mathrm{mg} \mathrm{Cu} / \mathrm{kg}$ diet gave results superior to those obtained with the $\mathrm{Cu}$ supplement alone.

5. When added to the diets alone, none of the three compounds tested nor $\mathrm{Cu}$ had any marked effect on any of the carcass measurements.

6. Arsanilic acid reduced total liver weight and markedly reduced the large increase in total liver $\mathrm{Cu}$ stores that resulted from supplementation of the diets with $250 \mathrm{mg} \mathrm{Cu} / \mathrm{kg}$ diet.
\end{abstract}

Barber, Braude \& Mitchell (1965) reported the results of three experiments with growing pigs in which the potential growth-promoting activities of $(a)$ zinc bacitracin (a narrow-spectrum antibiotic), (b) Protamone (an iodinated casein containing $1 \%$ thyroxine activity) and $(c)$ Emtryl (dimetridazole) were investigated in relation to the well-established growth-promoting effect of a dietary supplement of $250 \mathrm{mg} \mathrm{Cu} / \mathrm{kg}$ diet. None of the three materials had any effect on the performance of the pigs that suggested it would be either preferable to copper sulphate as a growth-promoter, or of value when added to : diet in addition to the $\mathrm{Cu}$ supplement. In the present paper, the results of investigations on three further materials are reported.

\section{EXPERIMENTAL}

All the experiments were similar in design and, in each, pigs were given three treatments and compared with a control group of pigs. The treatments were the addition to a control diet of either copper sulphate (providing $25^{\circ} \mathrm{mg} \mathrm{Cu} / \mathrm{kg}$ diet) alone, or one of the three materials being investigated alone, or copper sulphate and the material under investigation together. 


\section{Materials investigated}

Arsanilic acid. This is one of several organic arsenicals derived from phenylarsonic acid in which the arsenic present is in the pentavalent form. In the years following the work of Morehouse (I949) with poultry and of Carpenter (195I) with pigs, which suggested that organic arsenicals had a potential growth-promoting property, a considerable volume of experimental evidence was reported in the literature, mainly from the USA, confirming that continuous supplementation with arsenicals at a low level (up to Ioo $\mathrm{mg} / \mathrm{kg}$ diet) frequently improved the performance of growing pigs (see Anonymous (1956) for a general review of some of the earlier work with various species and Lennig Chemicals Ltd (1970) for a more recent review of a useful selection of the reported work with arsanilic acid in pigs, poultry and turkeys). The therapeutic value of some arsenicals when administered to pigs under certain conditions at high levels (up to $250 \mathrm{mg} / \mathrm{kg}$ diet) for short periods of time is also now well established, and their safety both for the animal itself and the potential consumer of the meat from such animals is well documented (see Frost, 1963, 1967).

Sodium salicylate. The antiseptic properties of salicylic acid (o-hydroxybenzoic acid) are well known, while its acetic acid ester (acetylsalicylic acid) is more widely known as 'aspirin'. Following the report by Rechka \& Kalous (1964) that a supplement of either sodium salicylate (100 mg/kg diet) or of sodium acetylsalicylate $(500 \mathrm{mg} / \mathrm{kg}$ diet) appeared to increase the growth rate of pigs, further papers from Czechoslovakia were subsequently published which, in the main, substantiated these findings (Müller \& Čulík, I965; Herzig \& Najman, 1966; Šatava, Štrunc, Rozman, Čulík \& Müller, I966; Müller, Satava, Vrchota \& Štrunc, I967; Rozman, I968 a, $b$ : Rozman \& Hejzlar, I970). Most of the reports were concerned with sodium salicylate, and levels giving responses ranged from 100 to $700 \mathrm{mg} / \mathrm{kg}$ diet.

Bromide salts. Eidrigevich, Osipov, Zaplatnikov, Bazarnyi, D’yakova \& Rumyantsev ( 1967 ) published results of several trials with growing pigs and fattening cattle given daily doses of a mixture of bromide salts. They reported that a daily intake of $5 \mathrm{mg} / \mathrm{kg}$ live weight of a mixture of sodium, potassium and ammonium bromides increased the rate of growth of the pigs. They noted an inhibition of sexual function while the bromides were being administered but, after withdrawal, representatives of both sexes were successfully used for breeding.

\section{Pigs and procedure}

For all three experiments, enzootic-pneumonia-free Large White pigs in litter-mate groups, balanced as far as possible for sex, were used. The pigs were selected after weaning (at 8 weeks of age) and were on experiment from 9-1o weeks of age (average initial weight $20 \mathrm{~kg}$ ) to $90 \mathrm{~kg}$ live weight. They were housed in a Danish-type piggery in pens of four; in any one pen, all four pigs received the same treatment, so there was no direct contact between pigs on different treatments. There were twelve pigs/ treatment in Expt I (arsanilic acid) and eight pigs/treatment in both Expt 2 (sodium salicylate) and Expt 3 (bromide salts).

All pigs were individually fed twice daily, 3.0 (Expt I) or 2.5 (Expts 2 and 3) 
water $/ \mathrm{kg}$ diet being added immediately before feeding, and at each meal the pigs were given access to the troughs for $30 \mathrm{~min}$. To commence with, the daily allowance was $\mathrm{I} \cdot 05 \mathrm{~kg}$ feed for a pig weighing $20 \mathrm{~kg}$; thereafter it was increased by $0 . \mathrm{I} \mathrm{kg}$ for each pig whenever its trough was completely cleared on 2 successive days, up to a maximum of $2.95 \mathrm{~kg}$ in Expts I and 3 and up to $3.0 \mathrm{~kg}$ in Expt 2. If a pig refused $20 \%$ or more feed on 2 successive days, the daily allowance was reduced by the estimated amount of the refused feed.

Table I. Expts I and 2. Percentage composition of basal diets received by all pigs

\begin{tabular}{|c|c|c|}
\hline & $\begin{array}{l}\text { Up to } 54 \mathrm{~kg} \\
\text { live weight }\end{array}$ & $\begin{array}{l}\text { From } 54 \mathrm{~kg} \\
\text { live weight } \\
\text { to slaughter }\end{array}$ \\
\hline Barley meal & 54 & 70 \\
\hline Fine wheat offal & 38 & 25 \\
\hline White fish meal & 7 & 3 \\
\hline Limestone flour & I & 0.75 \\
\hline Steamed bone flour & - & $I^{2}$ \\
\hline Salt & - & 0.25 \\
\hline Rovimix* (g/100 kg diet) & ro & $5 \cdot 6$ \\
\hline
\end{tabular}

- Roche Products Ltd, containing 50000 i.u. vitamin A and 12500 i.u. cholecalciferol/g.

Table 2. Expt 3. Percentage composition of basal diets received by all pigs

\begin{tabular}{|c|c|c|}
\hline & $\begin{array}{l}\text { Up to } 54 \mathrm{~kg} \\
\text { live weight }\end{array}$ & $\begin{array}{l}\text { From } 54 \mathrm{~kg} \\
\text { live weight } \\
\text { to slaughter }\end{array}$ \\
\hline Barley meal & $66 \cdot 75$ & $70 \cdot 25$ \\
\hline Fine wheat offal & 25 & 25 \\
\hline White fish meal & 7 & $3 \cdot 5$ \\
\hline Mineral-vitamin supplement* & $I \cdot 25$ & $\mathrm{I} \cdot 25$ \\
\hline
\end{tabular}

* Cooper Nutrition Products Ltd, supplying in the $12.5 \mathrm{~kg}$ added per $1000 \mathrm{~kg}$ diet: $4 \times 10^{6} \mathrm{i} . \mathrm{u}$. vitamin $\mathrm{A}, \mathrm{I} \times 10^{6} \mathrm{i}$.u. cholecalciferol, $2 \mathrm{~g}$ riboflavin, $8 \mathrm{~g}$ nicotinic acid, $6 \mathrm{~g}$ pantothenic acid, $2 \mathrm{mg}$ cyanocobalamin, $100 \mathrm{~g} \mathrm{Fe}, 70 \mathrm{~g} \mathrm{Zn,} 25 \mathrm{~g} \mathrm{Mn}, 5 \mathrm{~g} \mathrm{Cu}$, $1 \mathrm{~g} \mathrm{I}, 0.5 \mathrm{~g} \mathrm{Co}, 2.5 \mathrm{~kg} \mathrm{NaCl}, 9.6 \mathrm{~kg}$ limestone flour.

The compositions of the basal diets given in Expts $\mathrm{I}$ and 2 are shown in Table $\mathrm{I}$, and in Table 2 the basal diets used in Expt 3 are given. In the interval between the completion of Expts $I$ and 2 and the start of Expt 3, a number of changes were made in the composition of the standard control diets used in most of the feeding experiments with growing pigs at this Institute.

In all experiments, on treatments 2 and 4 (see Tables 3,4 and 5 ) the copper sulphate supplement $\left(\mathrm{CuSO}_{4} \cdot 5_{2} \mathrm{H}_{2} \mathrm{O}\right)$ used was in the form of a finely ground powder and was added to the basal diets at the level of $\mathrm{I} \mathrm{g} / \mathrm{kg}$ diet (supplying $25^{\circ} \mathrm{mg} \mathrm{Cu} / \mathrm{kg}$ diet). The arsanilic acid used was provided as Pro-Gen Premix (Abbott Laboratories Ltd, Queenborough, Kent) containing $25^{\circ} \mathrm{g}$ arsanilic acid $/ 2 \cdot 27 \mathrm{~kg}(5 \mathrm{lb})$ in a limestone flour base, and was added to the basal diets in Expt $\mathrm{I}$ at a level to supply roo $\mathrm{mg}$ arsanilic acid/kg diet for treatments 3 and 4 (see Table 3 ). In Expt 2, sodium salicylate was added to the basal diets at a level of $200 \mathrm{mg} / \mathrm{kg}$ diet for treatments 3 and 4 (see Table 4). For Expt 3, a bromide salt mixture consisting of equal parts of ammonium, 
potassium and sodium bromides as a finely ground powder was added to the basal diets for treatments 3 and 4 at a level of $200 \mathrm{mg} / \mathrm{kg}$ diet (see Table 5).

All experimental supplements except the bromide salt mixture were included in the diets throughout the experimental period. In Expt 3 the bromide salt supplement was withdrawn from the diet from the time the pigs reached a minimum live weight of $78 \mathrm{~kg}$ at the weekly weighing.

The pigs were weighed once a week and were sent to slaughter on the day after they had reached a minimum live weight of $89.5 \mathrm{~kg}$ at the weekly weighing; they were killed approximately i $9 \mathrm{~h}$ after their last feed. Carcass length, maximum thickness of shoulder fat and minimum thickness of loin fat were measured in accordance with the procedure used for commercial grading. Fat thickness over the eye muscle (longissimus dorsi), at the last rib in two positions (fat ' $\mathrm{C}$ ' and fat ' $\mathrm{K}$ ', approx. $4 \mathrm{~cm}$ and $9-10 \mathrm{~cm}$ respectively from the mid-line of the back), was also measured by means of an introscope on all carcasses.

At slaughter, the livers were collected from eight of the twelve litter-mate pigs on each of the four treatments in Expt $I$ and from all eight pigs on each of treatments $I, 2$ and 4 in Expt 2; no livers were collected from pigs in Expt 3. After the livers had been weighed, a sample of the tissue adjacent to the bile duct was taken and stored at $-20^{\circ}$ for subsequent determination of the $\mathrm{Cu}$ content; in unpublished earlier studies we established that the $\mathrm{Cu}$ concentration of a sample of liver taken from this position approximated closely to the mean $\mathrm{Cu}$ concentration of the whole liver. After digestion of the sample by a wet-ashing technique (Andrus, 1955), followed by an appropriate dilution, the $\mathrm{Cu}$ content of the solution was estimated by atomic absorption spectroscopy using a single beam instrument (Model A3000; Southern Instruments, Camberley, Surrey).

\section{Statistical methods}

Standard analyses of variance were done on each of the variables determined in each of the three experiments. For the liver $\mathrm{Cu}$ concentrations, logarithmic transformations were used as the within-treatment variances were heterogeneous.

\section{RESULTS}

Details of the results for Expts 1,2 and 3 are shown in Tables 3,4 and 5 respectively. All but one of the pigs in the three experiments grew normally for the full experimental period, the one animal being withdrawn from treatment 4 in Expt I on account of an abnormally slow rate of growth; missing values were substituted for the results for this pig.

\section{Expt I. Arsanilic acid (Table 3)}

Copper sulphate and arsanilic acid alone similarly and significantly improved the rate of growth of the pigs, but the interaction was large and there was no further improvement when both the supplements were added to the diet (treatment 4 ). Whereas Cu significantly improved the feed: gain ratio (feed conversion ratio or FCR) and had no effect on daily feed intake, arsanilic acid had no effect on FCR but significantly increased daily feed consumption. There was a significant interaction between 
the two supplements for this latter variable, arsanilic acid increasing daily feed intake only in the absence of $\mathrm{Cu}$ in the diet.

There were no significant differences between any of the treatments in their effect on dressing percentage, carcass length or thickness of shoulder fat. Neither copper

Table 3. Expt I (arsanilic acid). Mean daily weight gain, feed conversion ratio (FCR), carcass measurements, liver weight and liver copper content of pigs on treatments I-4 given no supplement, or a supplement of copper sulphate, or arsanilic acid, or both

(Twelve pigs/treatment on experiment from approximately 19 to $92 \mathrm{~kg}$ live weight; liver values based on eight pigs/treatment)

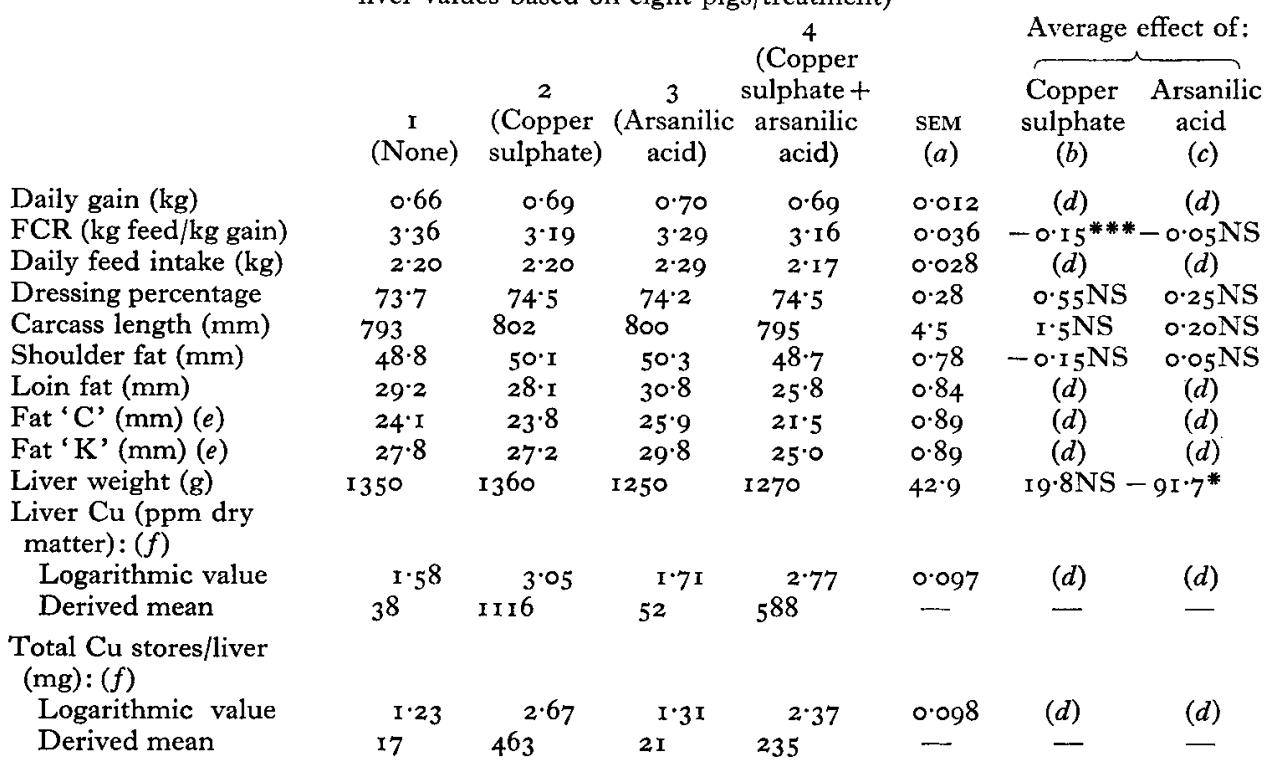

(a) Based on $32 \mathrm{df}$ (one pig withdrawn from treatment 4 and missing values substituted) with the exception of the liver weight and liver $\mathrm{Cu}$ values, for which there were $20 \mathrm{df}$ (one missing value on treatment 4).

(b) Treatments $[(2+4)-(\mathrm{I}+3)] \div 2$. Significance levels: NS, $P>0.05$; $0.05>P>0.01$; ** 0.01 $>P>0.001$; *** $P<0.001$.

(c) Treatments $[(3+4)-(1+2)] \div 2$. Significance levels as in $(b)$.

(d) The interaction between the two dietary supplements was large and average effects were not calculated.

(e) See p. 384 .

$(f)$ Logarithmic transformations were used in the analysis of variance, and both the logarithmic and derived means are shown.

sulphate nor arsanilic acid alone had any significant effect on the thickness of either loin fat or fat at position ' $\mathrm{C}$ ' or ' $\mathrm{K}$ ', but when the two supplements were given together there was a marked reduction in each of these three variables, the differences between values for treatments $I$ and 4 being significant for the loin and fat ' $K$ ' measurements.

Copper sulphate had no effect on liver weight, but significantly increased $\mathrm{Cu}$ concentration in the liver in both the absence and presence of arsanilic acid $(P<0.001)$. Arsanilic acid significantly reduced total liver weight, but had no significant effect on the concentration of $\mathrm{Cu}$ in the liver although, in the presence of dietary copper 
sulphate, both the concentration and total store of $\mathrm{Cu}$ in the liver were reduced by arsanilic acid (treatments 4 and 2), although the former difference was not quite significant at the $5 \%$ level.

\section{Expt 2. Sodium salicylate (Table 4)}

Copper sulphate and sodium salicylate alone similarly and significantly increased rate of growth and improved FCR, although with sodium salicylate (treatment 3 ) the difference for FCR did not quite attain the $5 \%$ level of significance. These responses to either supplement in the absence of the other were greater, although not significantly so, than those obtained when both supplements were added to the diet. There were no significant treatment differences or interaction for any of the carcass values shown in Table 4 with the exception that sodium salicylate significantly increased the thickness of shoulder fat.

Table 4. Expt 2 (sodium salicylate). Mean daily weight gain, feed conversion ratio (FCR), carcass measurements, liver weight and liver copper content of pigs on treatments $1-4$ given no supplement, or a supplement of copper sulphate, or sodium salicylate, or both

(Eight pigs/treatment on experiment from approximately 20 to $92 \mathrm{~kg}$ live weight)

\begin{tabular}{|c|c|c|c|c|c|c|c|}
\hline & \multirow[b]{2}{*}{$\begin{array}{c}\text { I } \\
\text { (None) }\end{array}$} & \multirow[b]{2}{*}{$\begin{array}{c}2 \\
\text { (Copper } \\
\text { sulphate) }\end{array}$} & \multirow[b]{2}{*}{$\begin{array}{c}3 \\
\text { (Sodium } \\
\text { salicylate) }\end{array}$} & \multirow{2}{*}{$\begin{array}{c}4 \\
\text { (Copper } \\
\text { sulphate + } \\
\text { sodium } \\
\text { salicylate) }\end{array}$} & \multirow[b]{2}{*}{$\begin{array}{l}\text { SEM } \\
(a)\end{array}$} & \multicolumn{2}{|c|}{ Average effect of: } \\
\hline & & & & & & $\begin{array}{l}\text { Copper } \\
\text { sulphate } \\
(b)\end{array}$ & $\begin{array}{l}\text { Sodium } \\
\text { salicylate } \\
\text { (c) }\end{array}$ \\
\hline Daily gain $(\mathrm{kg})$ & 0.74 & 0.80 & 0.79 & 0.76 & 0.013 & (d) & $(d)$ \\
\hline FCR (kg feed/kg gain) & $3 \cdot \pi \mathrm{I}$ & $2 \cdot 93$ & 3.00 & 3.04 & 0.038 & (d) & (d) \\
\hline Daily feed intake $(\mathrm{kg})$ & $2 \cdot 29$ & $2 \cdot 35$ & $2 \cdot 37$ & $2 \cdot 32$ & 0.034 & $0.002 \mathrm{NS}$ & $0.025 \mathrm{NS}$ \\
\hline Dressing percentage & $75 \cdot 9$ & $76 \cdot 0$ & $75 \cdot 7$ & $75 \cdot 9$ & 0.30 & $0.1 N S$ & $-0.2 \mathrm{NS}$ \\
\hline Carcass length $(\mathrm{mm})$ & 824 & $8 I_{7}$ & 834 & $8 \mathrm{r} 8$ & $6 \cdot 2$ & $-I I \cdot 2 N S$ & $5 \cdot 6 \mathrm{NS}$ \\
\hline Shoulder fat (mm) & $37 \cdot 2$ & $34 \cdot 0$ & $38 \cdot 4$ & $39^{\circ} 0$ & $I \cdot 13$ & $-\mathrm{I} \cdot 3 \mathrm{NS}$ & $3.1 *$ \\
\hline Loin fat $(\mathrm{mm})$ & $23 \cdot 0$ & $22 \cdot 6$ & $23 \cdot 9$ & $26 \cdot 0$ & $I \cdot 43$ & $0.9 \mathrm{NS}$ & $2 \cdot 1 N S$ \\
\hline Fat 'C' $(\mathrm{mm})(e)$ & $22 \cdot 5$ & $2 I \cdot 6$ & $21 \cdot 5$ & $23 \cdot 5$ & 0.96 & $0.6 \mathrm{NS}$ & $0.4 \mathrm{NS}$ \\
\hline Fat ' $\mathrm{K}$ ' $(\mathrm{mm})(e)$ & $24{ }^{\circ}$ & $22 \cdot 9$ & $23 \cdot 1$ & 24.1 & $I \cdot 18$ & $-0 . I N S$ & $0 \cdot 2 \mathrm{NS}$ \\
\hline Liver weight (g) & $135^{\circ}$ & 1320 & $(g)$ & 1320 & $37 \cdot 2$ & 一 & - \\
\hline $\begin{array}{l}\text { Liver } \mathrm{Cu}(\mathrm{ppm} \text { dry } \\
\text { matter):(f) }\end{array}$ & & & & & & & \\
\hline Logarithmic value & $I \cdot 8 I$ & $2 \cdot 91$ & $(g)$ & $2 \cdot 91$ & 0.049 & 一 & - \\
\hline Derived mean & 65 & 805 & $(g)$ & 805 & - & - & 一 \\
\hline
\end{tabular}

(a) Based on $2 \mathrm{I}$ df with the exception of the liver weight and liver $\mathrm{Cu}$ values, for which there were I $3 \mathrm{df}$ (one missing value on treatment 2 ).

(g) Samples not taken; average effects not determinable. For remaining footnotes see Table 3.

Copper sulphate, given alone or together with sodium salicylate, had no significant effect on liver weight. Copper sulphate significantly increased the liver Cu concentration, and the addition of sodium salicylate to the high-Cu diet (treatment 3 ) had no significant effect on this increase.

\section{Expt 3. Bromide salts (Table 5)}

Copper sulphate significantly increased rate of growth and improved FCR, whereas the bromide salts had no effect on either of these two variables. The performance of the pigs given both supplements tended to be inferior to that of pigs given $\mathrm{Cu}$ alone.

There were no significant treatment differences for any of the carcass measurements shown in Table 5, with the exception of carcass length. 
Table 5. Expt 3 (bromide salts). Mean daily weight gain, feed conversion ratio (FCR) and carcass measurements of pigs on treatments I-4 given no supplement, or a supplement of copper sulphate, or bromide salts, or both

(Eight pigs/treatment on experiment from approximately 19 to $92 \mathrm{~kg}$ live weight; fat ' $C$ ' and ' $K$ ' values based on seven pigs/treatment)

\begin{tabular}{|c|c|c|c|c|c|c|c|}
\hline & \multirow[b]{2}{*}{$\begin{array}{c}\text { I } \\
\text { (None) }\end{array}$} & \multirow[b]{2}{*}{$\begin{array}{c}2 \\
\text { (Copper } \\
\text { sulphate) }\end{array}$} & \multirow[b]{2}{*}{$\begin{array}{c}3 \\
\text { (Bromide } \\
\text { salts) }\end{array}$} & \multirow{2}{*}{$\begin{array}{c}4 \\
\text { (Copper } \\
\text { sulphate+ } \\
\text { bromide } \\
\text { salts) }\end{array}$} & \multirow[b]{2}{*}{$\begin{array}{l}\text { SEM } \\
(a)\end{array}$} & \multicolumn{2}{|c|}{ Average effect of: } \\
\hline & & & & & & $\begin{array}{l}\text { Copper } \\
\text { sulphate } \\
\text { (b) }\end{array}$ & $\begin{array}{l}\text { Bromide } \\
\text { salts } \\
\text { (c) }\end{array}$ \\
\hline Daily gain $(\mathrm{kg})$ & 0.74 & 0.82 & 0.75 & 0.78 & 0.013 & \multicolumn{2}{|c|}{$0.055^{* *}-0.017 \mathrm{NS}$} \\
\hline FCR (kg feed/kg gain) & $3 \cdot 16$ & $2 \cdot 90$ & $3 \cdot 12$ & 3.05 & 0.046 & $-0.17^{* *}$ & $0.06 \mathrm{NS}$ \\
\hline Daily feed intake $(\mathrm{kg})$ & $2 \cdot 32$ & $2 \cdot 36$ & $2 \cdot 32$ & $2 \cdot 37$ & 0.035 & $0.04 \mathrm{NS}$ & $0.004 \mathrm{NS}$ \\
\hline Dressing percentage & $76 \cdot 5$ & $75 \cdot 9$ & $76 \cdot 6$ & $76 \cdot 4$ & 0.52 & $-0.37 \mathrm{NS}$ & $0.29 \mathrm{NS}$ \\
\hline Carcass length (mm) & 802 & $82 I$ & $8 I_{4}$ & $80 \mathrm{I}$ & $4 \cdot 34$ & $(d)$ & (d) \\
\hline Shoulder fat (mm) & $39 \cdot 9$ & $39 \cdot 6$ & $38 \cdot 6$ & $39 \cdot 8$ & 0.90 & \multicolumn{2}{|c|}{$0.44 \mathrm{NS}-0.57 \mathrm{NS}$} \\
\hline Loin fat $(\mathrm{mm})$ & $25 \cdot 8$ & 25.4 & $25 \cdot 6$ & 23.9 & $\mathrm{I} \cdot \mathrm{OI}$ & \multicolumn{2}{|c|}{$-1.06 \mathrm{NS}-1.62 \mathrm{NS}$} \\
\hline Fat 'C' $(\mathrm{mm})(e)$ & $24 \cdot 4$ & 23.7 & $25 \cdot 4$ & 247 & $\mathrm{I} \cdot \mathrm{OI}$ & $-0.72 \mathrm{NS}$ & $1 \cdot 00 \mathrm{NS}$ \\
\hline Fat ' $\mathrm{K}$ ' $(\mathrm{mm})(e)$ & $29 \cdot 0$ & $29 \cdot 4$ & 30.9 & $29 \cdot 3$ & $I \cdot 26$ & $-0.57 \mathrm{NS}$ & $0.86 \mathrm{NS}$ \\
\hline
\end{tabular}

(a) Based on $2 \mathrm{I}$ df with the exception of the fat ' $C$ ' and ' $K$ ' values, for which there were $\mathrm{I} 6 \mathrm{df}$ (one missing value on treatment 2 and one on treatment 3 ).

For remaining footnotes see Table 3 .

\section{DISCUSSION}

In all three experiments, the responses to the addition of $250 \mathrm{mg} \mathrm{Cu} / \mathrm{kg}$ diet, namely growth responses of $5.5,9$ and $10 \%$ and improvements in FCR of $5,5.5$ and $8.25 \%$ in Expts 1,2 and 3 respectively, were within the range normally obtained with this supplement in growing pigs (Braude, I965; Wallace, 1967).

The growth responses to arsanilic acid in Expt $I$ and to sodium salicylate in Expt 2 confirm the reports in the literature, reviewed earlier, of similar responses to both compounds. In contrast, the negative results obtained with the bromide salts in Expt 3 were not in accord with the beneficial effects reported by Eidrigevich et al. (1967). Several other workers have reported responses in growth rate to arsenicals without significant effects on FCR, although some improvement in the latter appears to be more usually observed.

The magnitude of the growth response to arsanilic acid or to sodium salicylate was similar to that obtained with copper sulphate. A few comparisons of 3-nitro-4hydroxyphenylarsonic acid, added to the diet at the relatively low level of I $_{5}-30 \mathrm{mg} /$ $\mathrm{kg}$, with copper sulphate $\left(0 \cdot 5^{-1} \cdot 0 \mathrm{~g} / \mathrm{kg}\right.$ diet $)$ have been reported, and in every instance the mean growth response to the $\mathrm{Cu}$ supplement was greater than that observed with the arsenical (Foster, Speer, Hays \& Catron, 1958; Ruszczyc \& Glapś, I960, 1963; Hawbaker, Speer, Hays \& Catron, 196r).

No comparisons between salicylates and copper sulphate appear to have been reported, but, in connexion with the magnitude of the observed growth response to the supplement of $200 \mathrm{mg}$ sodium salicylate $/ \mathrm{kg}$ diet and its similarity to that obtained with copper sulphate in the experiment described here, it is of interest that recently Rozman (r968b) and Rozman \& Hejzlar (1970) reported that, during an experimental 
period of I I I d, growing pigs given an average dietary supplement of $700 \mathrm{mg}$ sodium salicylate $/ \mathrm{kg}$ grew $12 \%$ faster with a $9 \%$ better FCR than pigs given the salicylate at the level of $200 \mathrm{mg} / \mathrm{kg}$ diet used by us. In view of the relatively low cost of sodium salicylate, further investigation of its activity as a growth-promoting agent appears to be justified.

In spite of the significant increases in rate of growth obtained with either copper sulphate, arsanilic acid or sodium salicylate when added to the diet individually, there was clearly no synergistic effect when either of the two latter materials was given together with $\mathrm{Cu}$. Our results with copper sulphate plus arsanilic acid are in agreement with those reported by Foster $e t a l$. (1958) and Hawbaker $e t$ al. (1961), although the responses obtained by both these sets of workers with the arsenical alone were very low in comparison with the I $1-14 \%$ responses they obtained with copper sulphate alone.

The absence of any synergistic effect between $\mathrm{Cu}$ and either arsanilic acid or sodium salicylate parallels the results often observed in similar comparisons between $\mathrm{Cu}$ and certain antibiotics. At the same time, with $\mathrm{Cu}$ and antibiotics, synergistic effects have been observed under some conditions (Braude, I965), and hence the present results with arsanilic acid and sodium salicylate do not preclude the possibility of the occurrence of synergistic effects with $\mathrm{Cu}$ under other unspecified conditions.

The responses in performance in these experiments were all obtained without detriment to the quality of the carcasses as indicated by the measurements of length and fat thickness, with the single exception of a suggestion that sodium salicylate slightly increased shoulder-fat thickness. The absence of any significant effect of $\mathrm{Cu}$ on carcass quality is in agreement with the majority of reports in the literature (Braude, 1965). The observation in Expt I, that the addition of both $\mathrm{Cu}$ and arsanilic acid to the diet resulted in a marked reduction in the loin and introscope fat measurements, requires further investigation, particularly since there was no such effect when either of the two supplements was given separately.

The large increases in the concentration of $\mathrm{Cu}$ in the livers of the pigs given $\mathrm{Cu}-$ supplemented diets in Expts 1 and 2 (no liver analyses were made in Expt 3) were within the range of those previously observed (Braude, 1965). The reductions in liver weight and liver $\mathrm{Cu}$ concentration by arsanilic acid do not appear to have been previously reported, although a similar reduction in liver weight has been frequently observed as a result of dietary supplementation with either $\mathrm{Cu}$ or antibiotics (Barber, Braude, Chamberlain \& Mitchell, I96r), and it has been shown by several workers that the addition of $100-25^{\circ} \mathrm{ppm}$ zinc to a diet containing a supplement of $25^{\circ} \mathrm{ppm} \mathrm{Cu}$ reduces the liver $\mathrm{Cu}$ concentration to an extent similar to that brought about by arsanilic acid in the present experiment (see Allen, Barber, Braude \& Mitchell, 1958; Mills, I968; Haranhan \& O’Grady, I968; Ritchie, Luecke, Baltzer, Miller, Ullrey \& Hoefer, 1963). No determinations of liver arsenic concentration were made by us, but Hanson, Carpenter, Aunan \& Ferrin (1955) reported a mean liver arsenic concentration (ppm $\mathrm{As}_{2} \mathrm{O}_{3}$ in wet tissue) of 3.3 in pigs given $90 \mathrm{mg}$ arsanilic acid $/ \mathrm{kg}$ diet right through to the day of slaughter at about $90 \mathrm{~kg}$ live weight (as it was in the experiment reported here) and of $\mathrm{r} \cdot 4 \mathrm{ppm}$ when the arsanilic acid was withdrawn from 
the diet $7 \mathrm{~d}$ before slaughter. More recently, Gitter \& Lewis (I969) found 6.25 ppm $\mathrm{As}_{2} \mathrm{O}_{3}$ in the wet liver of pigs given $250 \mathrm{mg}$ arsanilic acid $/ \mathrm{kg}$ diet for $28 \mathrm{~d}$, which had fallen to $\mathrm{r} \cdot 0 \mathrm{ppm} 6 \mathrm{~d}$ after withdrawal. It is clearly desirable in relation to the use of organic arsenicals in pig feeds that the possible interactions, in respect of levels of liver storage, between these compounds and $\mathrm{Cu}$, and other minerals, should be further investigated.

Our thanks are due to Mrs J. Birchall for the statistical analyses of the experimental results.

\section{REFEREN CES}

Allen, M. M., Barber, R. S., Braude, R. \& Mitchell, K. G. (I958). Proc. Nutr. Soc. 17, xii.

Andrus, S. (1955). Analyst, Lond. 80, 5 I4.

Anonymous (1956). Nutr. Rev. 14, 206.

Barber, R. S., Braude, R., Chamberlain, A. G. \& Mitchell, K. G. (I96r). Int. Congr. Anim. Prod. viII. Hamburg 3, 86.

Barber, R. S., Braude, R. \& Mitchell, K. G. (1965). Br. F. Nutr. I9, 575.

Braude, R. (1965). Transactions of a Symposium on Cuprum pro Vita, Vienna, p. 55. Also published in Wld Rev. Anim. Prod. (1967) 3, 69.

Carpenter, L. E. (195 I). Archs Biochem. Biophys. 32, 181.

Eidrigevich, E. V., Osipov, K. V., Zaplatnikov, A. K., Bazarnyi, V. M., D'yakova, A. A. \& Rumyantsev, B. N. (1967). Vest. sel'-khoz. Nauki, Mosk. 12, no. I, p. 82.

Foster, J. R., Speer, V. C., Hays, V. W. \& Catron, D. V. (1958). F. Anim. Sci. 17, II77.

Frost, D. V. (1963). Western Feed and Seed. April.

Frost, D. V. (1967). Fedn Proc. Fedn Am. Socs exp. Biol. 26, I94.

Gitter, M. \& Lewis, G. (I969). Vet. Rec. 85, 389 .

Hanrahan, T. J. \& O'Grady, J. F. (1968). Anim. Prod. Io, 423.

Hanson, L. E., Carpenter, L. E., Aunan, W. J. \& Ferrin, E. F. (1955). F. Anim. Sci. 14, 5 13.

Hawbaker, J. A., Speer, V. C., Hays, V. W. \& Catron, D. V. (r96r). J. Anim. Sci. 20, 163.

Herzig, I. \& Najman, L. (1966). Biol. Chem. výz. zviř. 2, 483.

Lennig Chemicals Ltd (1970). Whitmoyer Tech. Bull. no. I I.

Mills, C. F. (1968). Feed Forum 3, 2 I.

Morehouse, N. F. (1949). Poult. Sci. 28, 375.

Müller, Z. \& Culik, J. (1965). Biol. Chem. výž. zviř. r, ıог.

Müller, Z., Satava, M., Vrchota, V. \& Strunc, M. (1967). Sb. vys. Sk. zeměd. provoz. ekon. Fak., Ceské Budéjovich 5, $5 \mathrm{I}$.

Rechka, J. \& Kalous, J. (1964). Sb. vys. Šk. zeméd. Praze p. 429.

Ritchie, H. D., Luecke, R. W., Baltzer, B. V., Miller, E. R., Ullrey, D. E. \& Hoefer, J. A. (I963). \%. Nutr. 79, II7.

Rozman, J. (1968a). Biol. Chem. výž. zviř. 4, 67.

Rozman, J. (1968b). Biol. Chem. výz. zviř. 4, 339.

Rozman, J. \& Hejzlar, Z. (1970). Biol. Chem. výz. zviř. 6, I79.

Ruszczyc, Z. \& Glapś, J. (1960). Roczn. Nauk. roln. 75-B-4, 54I.

Ruszczyc, Z. \& Glapś, J. (1963). Jb. Arbeitsgemeinsch. Fütterungsberat. 4, 193.

Satava, M., Sttrunc, M., Rozman, J., Culik, J. \& Müller, Z. (1966). Sb. vys. Sk. zeméd. provoz. ekon. Fak., Ceské Budějovich 4, 55.

Wallace, H. D. (1967). High Level Copper in Swine Feeding-a Review of Research in the U.S. New York and London: International Copper Research Association, Inc. 